\title{
Rhizome Yield of Sweet Flag (Acorus calamus L.) as Influenced by Planting Season, Harvest Time, and Spacing
}

\author{
R. K. S. Tiwari, ${ }^{1}$ K. Das, ${ }^{2}$ D. Pandey, ${ }^{1}$ R. B. Tiwari, ${ }^{1}$ and Jola Dubey ${ }^{3}$ \\ ${ }^{1}$ Department of Plant Pathology, T.C.B. College of Agriculture and Research Station, I.G.K.V., Bilaspur 495001, Chhattisgarh, India \\ ${ }^{2}$ Department of Botany, Government E.R.R.P.G. Science College, Bilaspur 495001, Chhattisgarh, India \\ ${ }^{3}$ Department of Biotechnology, Guru Ghasidas Central University, Bilaspur 495001, Chhattisgarh, India
}

Correspondence should be addressed to Jola Dubey, pandeyjola@rediffmail.com

Received 14 January 2012; Revised 20 March 2012; Accepted 23 April 2012

Academic Editor: David Clay

Copyright (c) 2012 R. K. S. Tiwari et al. This is an open access article distributed under the Creative Commons Attribution License, which permits unrestricted use, distribution, and reproduction in any medium, provided the original work is properly cited.

\begin{abstract}
A study was undertaken for two consecutive years to assess the possibility of optimizing rhizome yield of Acorus calamus L. (sweet flag) by shifting the time of planting (i.e., growing in rainy and autumn seasons), maintaining different spacings, and harvesting in different months. Significantly higher yields of A. calamus were recorded when seeded in autumn $\left(13150 \mathrm{~kg} \mathrm{ha}^{-1}\right)$ than rainy $\left(6570 \mathrm{~kg} \mathrm{ha}^{-1}\right)$ season. Harvesting of crop after 12 months gave maximum rhizome yields of $16470 \mathrm{~kg} \mathrm{ha}^{-1}$ and $9370 \mathrm{~kg} \mathrm{ha}^{-1}$ respectively during autumn and rainy seasons. A similar trend was also noticed in various yield components (i.e., length, width and weight of rhizome). Closer planting $(20 \times 20 \mathrm{~cm}, 30 \times 20 \mathrm{~cm})$ gave significantly higher rhizome yield $\left(8620 \mathrm{~kg} \mathrm{ha}^{-1}, 8120 \mathrm{~kg} \mathrm{ha}^{-1}\right)$ than wider spacing $40 \times 40 \mathrm{~cm}\left(7030 \mathrm{~kg} \mathrm{ha}^{-1}\right)$. This study illustrated the possibility of optimizing rhizome yield of $A$. calamus by manipulation in the time of planting and harvesting as well as maintaining proper plant spacing.
\end{abstract}

\section{Introduction}

Rice is grown as major staple food for 2.7 billion people in Asia alone [1]. Rice (Oryza sativa Linn.) ecosystem occupies a preeminent place in Indian agriculture constituting nearly $67 \%$ of the net cultivated area [2]. Among agricultural crops, rice is the only predominantly grown crop in waterlogged soil. However, rice cultivation has its own limitation due to association of several problems, that is, no planting is possible if monsoon delayed, failure of crop if flood occurs, zinc deficiency for rice and following season crop, and use of huge quantity of hazardous pesticides for the control of several insect-pests and diseases, also rice soil is considered as one of the important sources of large-scale $\mathrm{CH}_{4}$ emission [3]. Waterlogged soils affected with aeration stress constitute about $5.7 \%$ of total land area and $10.3 \%$ of total net sown area in India. These lands are either lying vacant or having very low productivity of rice [3]. Several pulses and oil seed crops have been tried as main crops and intercrops during the kharif seasons with irrigated rice ecosystem but none of the crop is found suitable in producing higher yield than rice due to continuous submergence for longer period [4].
After rice harvest sufficient moisture is maintained in the field for a longer period. This situation can be efficiently utilized to grow some other crops having longer duration in or intercropping system with rice.

In the recent years, medicinal plants are being grown as main crops and intercrops with rice under irrigated condition to accrue more economic return from the same field [5]. Sweet flag (Acorus calamus L.) may be grown successfully without much loss in productivity due to its photo thermal insensitive nature, ability to withstand soil aeration stress, and other desirable characters like type of crop produce (rhizome and leaves) [3]. Inclusion of this herb in waterlogged area will help in crop diversification with inherent ability to grow under extremes of high soil moisture and limit the problem of excess water. Its economic importance is increased when products for the pharmaceutical sector are considered [6-8]).

Acorus calamus L., commonly known as sweet flag, belongs to the family Araceae (Adoraceae). The genus Acorus is derived from "Acoron" (coreon = the pupil of the eye) and the species calamus is derived from the Greek word "Calamos" (a reed). It is commonly known as Bach in India. 
This perennial herb, which is indigenous to central Asia, India, and the Himalayan region, is found commonly on the banks of streams and in damp marshy places. Bach has a cylindrical rhizome with a diameter of 3 to $4 \mathrm{~cm}$. The plant changes from pale green to pink as it matures. The leaf scars are brown, white, and spongy. The plant possesses slender roots, and its leaves are few and distichously alternate [9]. The rhizome of $A$. calamus has various medicinal properties.

The rhizome is the source of an essential oil, which is a unique source of oxygenated sesquiterpenes of great structural variety and responsible for significant antibacterial, antifungal, and insecticidal properties [10]. Apart from the terpenes, a few commonly occurring steroids and xanthones had also been reported. It was also used as a constituent of polyherbal formulation, namely herbal multiaction skin gel, which was found to be effective against a variety of specific and nonspecific dermatitis and maggot wounds [11]. The alcoholic extract of $A$. calamus rhizome exhibited potent antiviral activity against herpes viruses, that is HSV-1 and HSV-2 [12]. The ethanolic extract of the rhizome is used as antiulcer agent that inhibits gastric secretion and protects gastroduodenal mucosa against the injuries caused by pyloric ligation in rats [13]. $\beta$-asarone isolated from the volatile fraction of A. calamus was found to exhibit anticarcinogenic action on $\mathrm{ED}_{50}$ of SGC cells at a dose level of $25 \mathrm{mcg} / \mathrm{ml} \mathrm{[14].}$

Extractives of $A$. calamus rhizome for calamus oil are widely used now in pharmaceuticals and traditional systems of medicines for a number of ailments and in perfumes [15]. Thus, it is a common item in the international drug market and the raw material is originated from the natural wild populations [16]. Due to the indiscriminate collection of the plant materials from forest, its wild population levels are rapidly decreasing. McAlpine and Warrier [17] reported that sweet flag belongs among the endangered medicinal plants and its population was reported to be decreasing rapidly. This catastrophic decrease of sweet flag populations calls for an immediate conservation of its genetic resources and for starting targeted sweet flag field cultivation so that the raw material demand can be satisfied. A. calamus is cultivated throughout India, up to altitudes of about $2200 \mathrm{~m}$ [18]. It is known that improvement of crop cultivation technology for local climatic and edaphic factors is imperative for successful crop production.

A. calamus is a annual long-day plant with life cycle of one year in general. It can yield 10-12 tons of rhizomes per hectare as a sole crop $[19,20]$. Date of sowing plays a major role in the accumulation of growing degree days (GDDs) and photo thermal units (PTUs) from sowing to maturity of crop. Daily GDD and PTU values are added together from the beginning of the season, providing an indication of the energy available for growth. GDD and PTU are the energy terms obtained by air temperatures and bright sunshine hours and are used for comparing growth progresses, estimating crop development stages and harvest time. GDD is the number of temperature degrees determining proportional crop growth and development, whereas PTU represents the product of GDD and the possible sunshine hours that are potentially influenced by the geographical region.
The different crop developmental stages are completed once a given number of GDDs or PTUs are reached [21].

Keeping in mind the above perspectives, the present investigation has been undertaken aiming to optimize the rhizome yield under good crop management and favorable agroclimatic conditions. The objectives of this study were to determine the influence of planting date, harvesting date, and planting space on rhizome yields.

\section{Materials and Methods}

The field experiments were carried out at the experimental farms of Thakur Chhedilal Barrister College of Agriculture and Research Station, Bilaspur, Chhattisgarh, India during cropping seasons of 2006-07 and 2007-08. The experimental farm is located at $22^{\circ} 9^{\prime} 12^{\prime \prime}$ north latitude, $82^{\circ} 12^{\prime} 12^{\prime \prime}$ east longitude, and at an altitude of $292.3 \mathrm{~m}$ MSL. The climate of Bilaspur is subhumid. The air temperature varies from a minimum of about $4.6^{\circ} \mathrm{C}$ (in December-January) to a maximum of about $45.0^{\circ} \mathrm{C}$ (in May). The relative humidity ranges from about 12.0 during May to 92.0 during JulyAugust. Average annual rainfall is $1250 \mathrm{~mm}$, of which $82 \%$ is received during June to September [22]. Mean monthly meteorological data during the experimental period is presented in Table 1. The two set of experiments, influence of seasons and harvest time and influence of spacing, were based on rhizome yield and yield-dependant parameters of A. calamus and performed for two consecutive years, 2006-07 and 2007-08. In the first set of experiments, the crop was planted in rainy season (crop period, July to June) and autumn season (crop period, January to December) with plant spacing of $30 \mathrm{~cm} \times 30 \mathrm{~cm}$ and harvested after 7 , $8,9,10,11$, and 12 months after planting. In the second set of experiments the crop was planted in autumn season with different spacings $20 \times 20 \mathrm{~cm}, 30 \times 20 \mathrm{~cm}, 30 \times 30 \mathrm{~cm}, 40 \times$ $30 \mathrm{~cm}$, and $40 \times 40 \mathrm{~cm}$ and harvested after 10 months after planting (Figure 3 ). The field experiments were laid out in all sides bunded plots of $3.85 \mathrm{~m} \times 3.5 \mathrm{~m}$ with three replications in randomized block design. Farm yard manure was uniformly (@1000 $\mathrm{kg} \mathrm{ha}^{-1}$ ) applied at the time of field preparation. Crop was fertilized with nitrogen, phosphorus, and potassium in ratio of $100: 40: 40 \mathrm{~kg} \mathrm{ha}^{-1}$. Yield $\left(\mathrm{kg} \mathrm{ha}^{-1}\right)$ and yield-attributing characteristics $\left(\right.$ plant $^{-1}$ ) (i.e., length $(\mathrm{cm})$, width $(\mathrm{cm})$, and weight $(\mathrm{g})$ of rhizome) for each treatment were recorded. The gathered data were statistically analyzed to determine treatment differences [23].

The Agrometeorological indices GDD and PTU were computed based on weather data. The GDD was calculated following the procedure as described by McMaster and Wilhelm [24], while PTU was calculated by using the equation given by Wilsie [25]:

$$
\begin{aligned}
\mathrm{GDD} & =\left(\frac{\left(T_{\max }+T_{\min }\right)}{2}\right)-T_{\text {base }}, \\
\mathrm{PTU} & =(\mathrm{GDD} \times L),
\end{aligned}
$$

where $T_{\max }$ and $T_{\min }$ are the daily maximum and minimum air temperature $\left({ }^{\circ} \mathrm{C}\right)$ and $T_{\text {base }}$ is the base temperature $\left({ }^{\circ} \mathrm{C}\right)$, 
TABLE 1: Mean monthly weather data of Bilaspur, Chhattisgarh, India (Year 2006-2008).

\begin{tabular}{|c|c|c|c|c|c|c|c|c|c|c|c|c|c|}
\hline \multirow{2}{*}{ Parameter } & \multirow{2}{*}{ Year } & \multicolumn{12}{|c|}{ Month } \\
\hline & & Jan & Feb & Mar & Apr & May & Jun & Jul & Aug & Sep & Oct & Nov & Dec \\
\hline \multirow{3}{*}{ MAX } & 2006 & 28.2 & 33.2 & 33.0 & 38.6 & 40.1 & 38.5 & 30.2 & 30.1 & 42.2 & 32.4 & 29.8 & 28.0 \\
\hline & 2007 & 27.9 & 29.4 & 32.9 & 39.0 & 40.4 & 37.5 & 30.1 & 31.3 & 31.5 & 31.1 & 29.2 & 27.5 \\
\hline & 2008 & 27.5 & 27.4 & 34.8 & 39.1 & 41.7 & 34.3 & 32.2 & 31.7 & 32.3 & 32.1 & 30.1 & 29.3 \\
\hline \multirow{3}{*}{ MIN } & 2006 & 10.2 & 13.8 & 17.9 & 21.7 & 25.9 & 26.4 & 24.8 & 24.4 & 24.3 & 19.9 & 16.4 & 12.1 \\
\hline & 2007 & 11.1 & 14.7 & 17.6 & 22.1 & 25.0 & 26.4 & 24.6 & 24.3 & 24.4 & 18.9 & 14.2 & 11.6 \\
\hline & 2008 & 11.8 & 11.6 & 18.2 & 21.0 & 25.4 & 25.1 & 25.0 & 25.1 & 24.1 & 19.4 & 15.3 & 12.0 \\
\hline \multirow{3}{*}{ SS } & 2006 & 87.0 & 83.0 & 82.0 & 67.0 & 63.0 & 75.0 & 91.0 & 92.0 & 91.0 & 92.0 & 91.0 & 92.0 \\
\hline & 2007 & 8.9 & 9.0 & 9.4 & 9.5 & 9.3 & 5.8 & 4.2 & 3.8 & 5.0 & 8.8 & 11.7 & 8.6 \\
\hline & 2008 & 8.2 & 8.1 & 8.6 & 10.2 & 9.3 & 3.2 & 3.9 & 4.1 & 7.0 & 8.8 & 7.7 & 8.5 \\
\hline \multirow{3}{*}{ EVP } & 2006 & 3.0 & 4.1 & 4.8 & 6.5 & 7.1 & 6.6 & 3.0 & 3.0 & 3.6 & 3.6 & 2.6 & 2.5 \\
\hline & 2007 & 2.8 & 3.7 & 4.9 & 6.4 & 6.9 & 6.5 & 3.2 & 2.9 & 3.1 & 3.3 & 2.8 & 2.4 \\
\hline & 2008 & 2.6 & 3.1 & 4.7 & 6.4 & 8.3 & 4.6 & 3.9 & 3.4 & 3.8 & 3.3 & 2.7 & 2.4 \\
\hline \multirow{3}{*}{$\mathrm{RF}$} & 2006 & 0.0 & 0.0 & 45.8 & 12.8 & 67.0 & 67.6 & 353.6 & 299.8 & 130.2 & 11.6 & 1.4 & 0.0 \\
\hline & 2007 & 0.0 & 77.4 & 48.6 & 10.2 & 22.4 & 218.2 & 341.8 & 461.8 & 118.4 & 12.0 & 0.0 & 0.0 \\
\hline & 2008 & 1.4 & 14.6 & 12.6 & 29.6 & 4.4 & 280.2 & 165.4 & 241.0 & 213.8 & 15.4 & 6.4 & 0.0 \\
\hline \multirow{3}{*}{$\mathrm{RD}$} & 2006 & 0.0 & 0.0 & 8.0 & 3.0 & 3.0 & 6.0 & 17.0 & 20.0 & 10.0 & 2.0 & 1.0 & 0.0 \\
\hline & 2007 & 0.0 & 2.0 & 2.0 & 2.0 & 6.0 & 13.0 & 18.0 & 20.0 & 12.0 & 1.0 & 0.0 & 0.0 \\
\hline & 2007 & 1.0 & 2.0 & 2.0 & 2.0 & 2.0 & 17.0 & 19.0 & 17.0 & 10.0 & 1.0 & 1.0 & 0.0 \\
\hline
\end{tabular}

Source: Agro-Meteorology Observatory of TCB College of Agriculture and Research Station (IGKV), Bilaspur, Chhattisgarh, Inida.

MAX is the maximum temperature $\left({ }^{\circ} \mathrm{C}\right), \mathrm{MIN}$ is the minimum temperature $\left({ }^{\circ} \mathrm{C}\right), \mathrm{RH}$ is the relative humidity (\%), SS is the sunshine hour (hr/day), EVP is the evaporation, $\mathrm{RF}$ is the rainfall ( $\mathrm{mm})$, and $\mathrm{RD}$ is the rainy days.

below which crop development stops, and $L$ is the maximum possible sunshine hours.

\section{Results and Discussion}

The results of experiment 1 are shown in Tables 2 and 3 . Data obtained from two years of experimentation indicated that there was a significant $(P \leq 0.05)$ increase in rhizome yield and yield-attributing parameters (i.e. rhizome length, rhizome width, and rhizome weight) of A. calamus harvested 7 months and 12 months after planting in both the cropping seasons (Figure 1). The highest rhizome yields $\left(16850 \mathrm{~kg} \mathrm{ha}^{-1}\right)$ was measured when the crop was seeded in the autumn of 2007-2008 and harvested 12 months later. The lowest yields $\left(3430 \mathrm{~kg} \mathrm{ha}^{-1}\right)$ were observed when it was seeded in the rainy season of 2006-2007 and harvested 7 months later.

Data presented in Table 2 indicated that the crop planted in autumn season had double rhizome yield (13150 $\left.\mathrm{kg} \mathrm{ha}^{-1}\right)$ on average when compared to the crop planted in rainy season $\left(6570 \mathrm{~kg} \mathrm{ha}^{-1}\right)$. Increase in rhizome yield during autumn season might be due to prevailing favorable optimum meteorological conditions during the entire crop season. The higher rhizome yield recoded for planting in autumn might be due to greater physiological activities of plants in the presence of greater amount of bright sunshine and other favorable meteorological parameters. There was significant increase in rhizome yield of $A$. calamus harvested between 7 months and 12 months. However, yields of 11 months and 12 months were almost equal and statistically nonsignificant

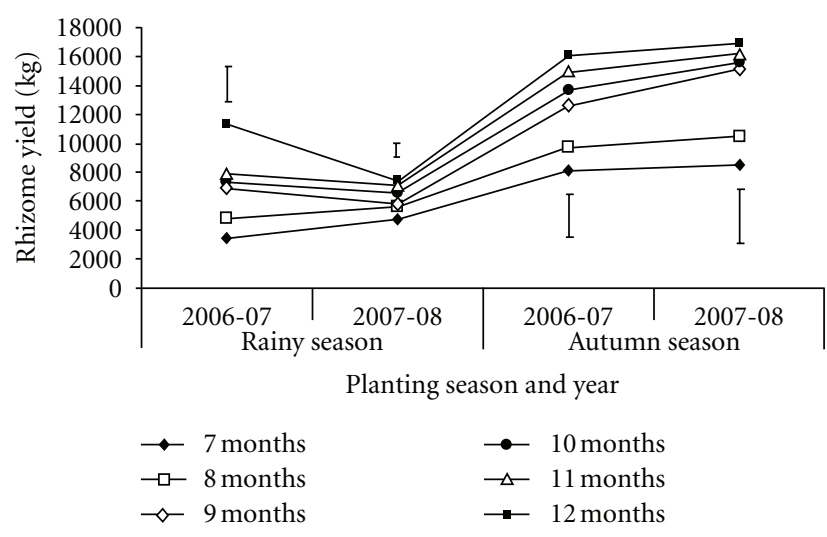

Figure 1: Rhizome yield of Acorus calamus (sweet flag) harvested at different durations over two seasons and two years. Bars indicate $\mathrm{CD}_{0.05}$ within the same treatment and year.

during both seasons (Table 2; Figure 1). Percent increase in yield, based on the mean yield of two years, revealed a declining trend between 7-8 (22.3\%) months and 10-11 (7.2\%) months after planting and then an increase at 11-12 months after planting $(20.3 \%)$ during the rainy season. In autumn the percent increase in rhizome yield was the highest $(27.3 \%)$ at $8-9$ months followed by 11-12 (20.3\%) months after planting, whereas the minimum increase $(5.3 \%)$ was at 9-10 months after planting (Figure 2). A close scrutiny of Figure 2 and long-term mean weather data revealed that percent increase in rhizome yield was higher when the crop received either cooler air temperatures or rain. For example, 
TABLE 2: Rhizome yield of Acorus calamus (sweet flag) harvested at different durations over two seasons and years.

\begin{tabular}{|c|c|c|c|c|c|c|}
\hline \multirow{3}{*}{ Harvest time } & \multicolumn{6}{|c|}{ Seasonal rhizome yield (kg/ha) } \\
\hline & \multicolumn{3}{|c|}{ Rainy } & \multicolumn{3}{|c|}{ Autumn } \\
\hline & 2006-2007 & 2007-2008 & Mean & 2006-2007 & $2007-2008$ & Mean \\
\hline At 7 th month & 3430 & 4720 & 4080 & 8120 & 8500 & 8310 \\
\hline At 8th month & 4840 & 5660 & 5250 & 9710 & 10450 & 10080 \\
\hline At 9 th month & 6890 & 5780 & 6340 & 12600 & 15110 & 13860 \\
\hline At 10 th month & 7300 & 6560 & 6930 & 13640 & 15610 & 14630 \\
\hline At 11 th month & 7850 & 7080 & 7470 & 14910 & 16140 & 15530 \\
\hline At 12 th month & 11350 & 7390 & 9370 & 16080 & 16850 & 16470 \\
\hline Trial Mean & 6940 & 6200 & 6570 & 12510 & 13780 & 13150 \\
\hline C.D. at $5 \%$ & 1355 & 528 & & 1679 & 2161 & \\
\hline C.V. & 10.73 & 4.69 & & 8.61 & 8.76 & \\
\hline
\end{tabular}

TABLE 3: Yield-dependant parameters of Acorus calamus (sweet flag) harvested at different durations over two seasons and years.

\begin{tabular}{|c|c|c|c|c|c|c|c|c|c|c|c|c|c|c|c|c|c|c|}
\hline \multirow{4}{*}{ Harvest time } & \multicolumn{18}{|c|}{ Seasonal rhizome yield parameters plant ${ }^{-1}$} \\
\hline & \multicolumn{9}{|c|}{ Rainy } & \multicolumn{9}{|c|}{ Autumn } \\
\hline & \multicolumn{3}{|c|}{$2006-2007$} & \multicolumn{3}{|c|}{ 2007-2008 } & \multicolumn{3}{|c|}{ Mean } & \multicolumn{3}{|c|}{ 2006-2007 } & \multicolumn{3}{|c|}{ 2007-2008 } & \multicolumn{3}{|c|}{ Mean } \\
\hline & $\mathrm{L}$ & B & $\mathrm{W}$ & $\mathrm{L}$ & B & $\mathrm{W}$ & $\mathrm{L}$ & B & $\mathrm{W}$ & $\mathrm{L}$ & $\mathrm{B}$ & $\mathrm{W}$ & $\mathrm{L}$ & B & W & $\mathrm{L}$ & B & W \\
\hline At 7th month & 61.8 & 1.4 & 0.2 & 58.9 & 1.2 & 0.3 & 60.4 & 1.3 & 0.3 & 61.2 & 1.4 & 0.4 & 63.5 & 1.5 & 0.6 & 62.4 & 1.5 & 0.5 \\
\hline At 8th month & 69.1 & 1.3 & 0.2 & 63.9 & 1.2 & 0.4 & 66.5 & 1.3 & 0.3 & 63.0 & 1.5 & 0.5 & 62.0 & 1.8 & 0.7 & 62.5 & 1.7 & 0.6 \\
\hline At 9th month & 75.4 & 1.4 & 0.3 & 67.6 & 1.3 & 0.5 & 71.5 & 1.4 & 0.4 & 74.5 & 1.6 & 0.6 & 81.4 & 1.8 & 0.7 & 78.0 & 1.7 & 0.7 \\
\hline At 10 th month & 76.6 & 1.5 & 0.3 & 72.2 & 1.4 & 0.5 & 74.4 & 1.5 & 0.4 & 88.1 & 1.6 & 0.8 & 103.9 & 1.9 & 1.0 & 96.0 & 1.8 & 0.9 \\
\hline At 11 th month & 92.2 & 1.5 & 0.4 & 81.9 & 1.4 & 0.5 & 87.1 & 1.5 & 0.5 & 98.6 & 1.7 & 0.7 & 115.3 & 2.0 & 0.9 & 107.0 & 1.9 & 0.8 \\
\hline At 12 th month & 97.6 & 1.6 & 0.5 & 89.5 & 1.5 & 0.6 & 93.6 & 1.6 & 0.6 & 101.9 & 1.7 & 0.8 & 114.2 & 2.0 & 0.9 & 108.1 & 1.9 & 0.9 \\
\hline Trial Mean & 78.8 & 1.4 & 0.3 & 72.3 & 1.4 & 0.5 & 75.6 & 1.4 & 0.4 & 81.2 & 1.6 & 0.6 & 90.1 & 1.8 & 0.8 & 85.7 & 1.7 & 0.7 \\
\hline C.D. at $5 \%$ & 17.9 & 0.2 & 0.1 & 15.3 & 0.5 & 0.1 & 16.6 & 0.4 & 0.1 & 5.9 & 0.1 & 0.1 & 9.7 & 0.1 & 0.2 & 7.8 & 0.1 & 0.2 \\
\hline C.V. & 12.5 & 7.0 & 9.1 & 10.1 & 5.9 & 8.8 & 11.3 & 6.5 & 9.0 & 4.9 & 4.0 & 8.2 & 5.9 & 2.4 & 10.8 & 5.4 & 3.2 & 9.5 \\
\hline
\end{tabular}

L: length $(\mathrm{cm})$, B: width $(\mathrm{cm})$, and W: weight $(\mathrm{kg})$.

7-8 and 8-9 months after planting in both of the seasons over two years experienced a higher percent yield increase, which signifies the period between January-February (lower temperature) and July-August (rainy days). Similarly, higher percent yield increase in autumn season at 11-12 months after planting signifies the colder period between NovemberDecember. Pooled data on rhizome yield, irrespective of season and year was highest $\left(12920 \mathrm{~kg} \mathrm{ha}^{-1}\right)$ when harvested after 12th months (Table 2) followed by 11 th months $\left(11490 \mathrm{~kg} \mathrm{ha}^{-1}\right)$. Thus, the trends indicated that the crop requires at least a maximum period of 11-12 months to produce optimum rhizome yield. Shifting the time of planting from rainy season to autumn season had a significantly greater impact on the crops yield potential. Meteorological data presented in Table 1 indicated that the crop planted in autumn season received a higher number of sunshine hours and high temperature, which led to optimum growth of the plant, which resulted in an increase in rhizome yield.

Data on yield-contributing characteristics of A. calamus indicated that the autumn season was more productive than the rainy season over two years of cropping, which was in correlation with the findings on bulk rhizome yield discussed earlier (Table 3). Perusal of Table 3 depicted that mean rhizome length plant ${ }^{-1}$, width plant ${ }^{-1}$, and weight plant ${ }^{-1}$

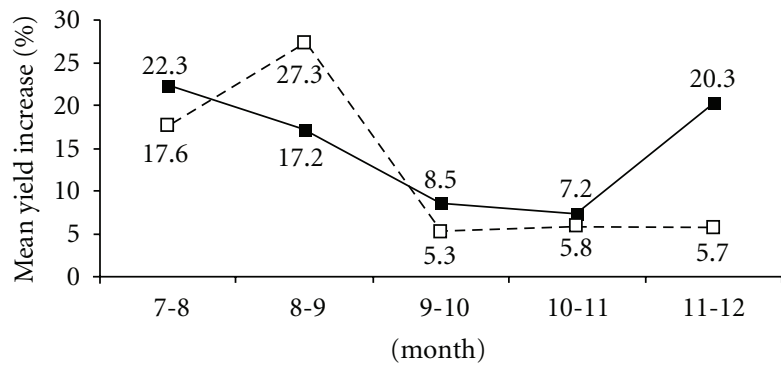

Harvest month transitions

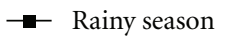

$-\square-$ Autumn season

Figure 2: Percent increase in rhizome yield $\left(\mathrm{kg} \mathrm{ha}^{-1}\right)$ at different harvest transitions, calculated based on the mean value of individual cropping seasons (rainy and autumn).

were all higher in autumn season compared to rainy season. Moreover, pooled data across seasons and years revealed that all yield-dependant parameters, that is, rhizome length plant $^{-1}$, width plant ${ }^{-1}$, and weight plant ${ }^{-1}$, were significantly higher $(P \leq 0.05)$ from the crop harvested after 12 months (Table 3) during autumn season of 2007-08. Similarly, 

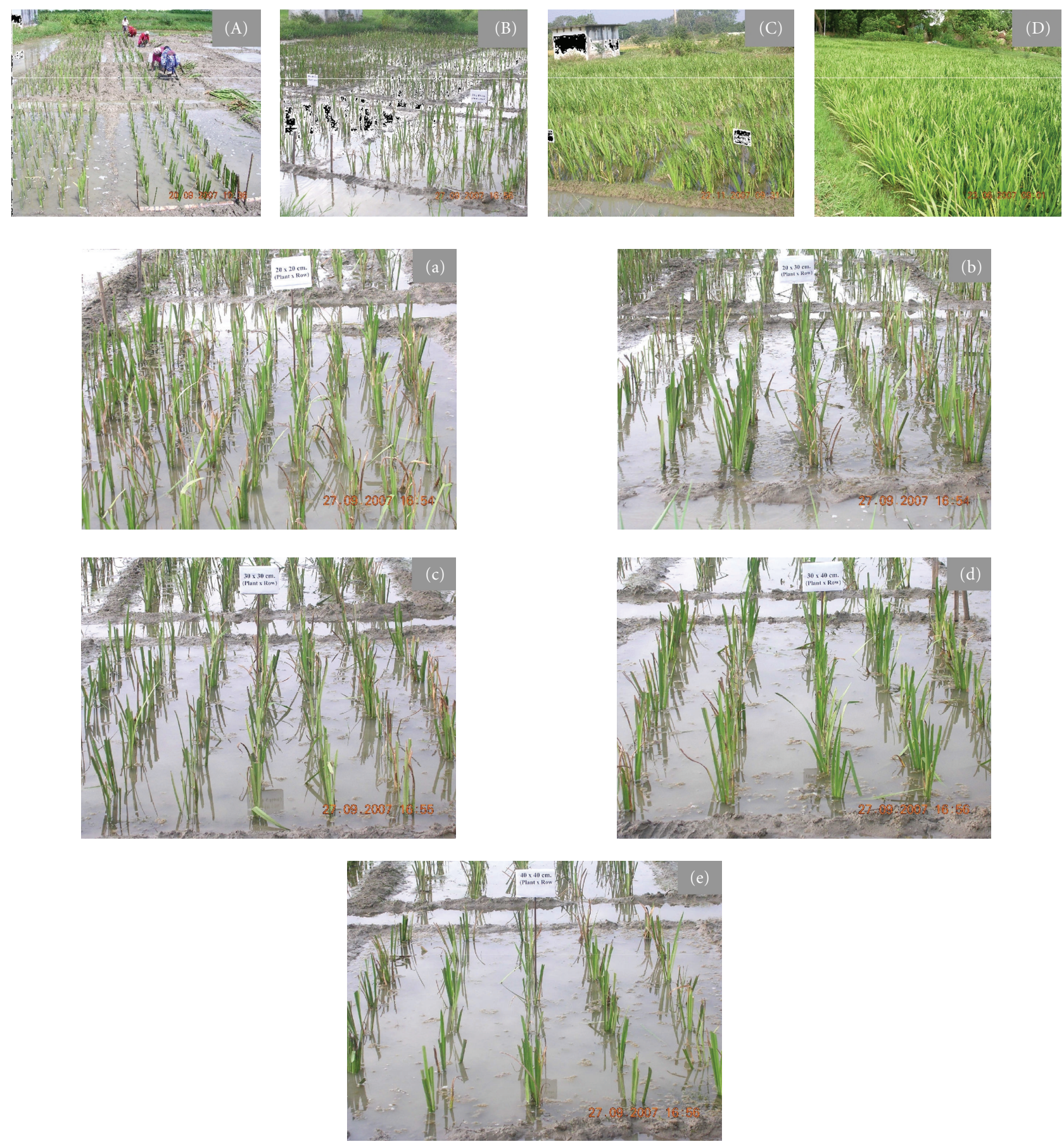

Figure 3: View of experimental plot ((A) at planting; (B) after 3 months; (C) after 6 months; (D) after 12 months) and different spacing treatments ((a) $20 \times 20 \mathrm{~cm}$; (b) $20 \times 30 \mathrm{~cm}$; (c) $30 \times 30 \mathrm{~cm}$; (d) $30 \times 40 \mathrm{~cm}$; (e) $40 \times 40 \mathrm{~cm}$ ).

significantly higher yield of paddy was also recorded during autumn season than rainy season [26].

Growing degree days (GDDs) and photo thermal units (PTUs) estimated from the crop planted in autumn season and rainy season and harvested in different months indicated that both the parameters were found to be on higher side during autumn season and led to higher rhizome yield (Table 5). Meteorological data presented in Table 1 indicated that the crop planted in autumn season received higher number of sunshine hours and high temperature, which led to optimum growth of the plant that resulted in an increase in rhizome yield. Two years and single-season (autumn) results presented in Table 4 show that there was a significant $(P \leq 0.05)$ effect of plant spacing on the growth and rhizome yield of A. calamus. The highest rhizome yield $\left(8740 \mathrm{~kg} \mathrm{ha}^{-1}\right)$ was recorded in $30 \times 20 \mathrm{~cm}$ spacing in 2007-08 followed 
TABle 4: Rhizome yield and yield-dependant parameters of Acorus calamus (sweet flag) planted with different spacings and harvested in single season over two year.

\begin{tabular}{|c|c|c|c|c|c|c|c|c|c|c|c|c|}
\hline \multirow{3}{*}{ Spacing } & \multicolumn{9}{|c|}{ Rhizome yield parameters in autumn season plant ${ }^{-1}$} & \multicolumn{3}{|c|}{ Rhizome yield in autumn season $(\mathrm{kg} / \mathrm{ha})$} \\
\hline & \multicolumn{3}{|c|}{ 2006-2007 } & \multicolumn{3}{|c|}{$2007-2008$} & \multicolumn{3}{|c|}{ Mean } & \multirow[b]{2}{*}{ 2006-2007 } & \multirow[b]{2}{*}{$2007-2008$} & \multirow[b]{2}{*}{ Mean } \\
\hline & $\mathrm{L}$ & $\mathrm{B}$ & $\mathrm{W}$ & $\mathrm{L}$ & B & $\mathrm{W}$ & $\mathrm{L}$ & $\mathrm{B}$ & $\mathrm{W}$ & & & \\
\hline $20 \times 20 \mathrm{~cm}$ & 83.8 & 1.5 & 0.4 & 95.2 & 1.6 & 0.9 & 89.5 & 1.6 & 0.7 & 8660 & 8570 & 8620 \\
\hline $30 \times 20 \mathrm{~cm}$ & 80.9 & 1.5 & 0.4 & 93.3 & 1.5 & 0.9 & 87.1 & 1.5 & 0.6 & 7500 & 8740 & 8120 \\
\hline $30 \times 30 \mathrm{~cm}$ & 78.7 & 1.4 & 0.3 & 90.8 & 1.4 & 1.0 & 84.7 & 1.4 & 0.7 & 6470 & 6410 & 6440 \\
\hline $40 \times 30 \mathrm{~cm}$ & 74.3 & 1.5 & 0.4 & 91.5 & 1.4 & 1.0 & 82.9 & 1.4 & 0.6 & 6910 & 6060 & 6490 \\
\hline $40 \times 40 \mathrm{~cm}$ & 77.5 & 1.4 & 0.4 & 84.1 & 1.4 & 0.9 & 80.8 & 1.4 & 0.7 & 6390 & 7660 & 7030 \\
\hline Trial Mean & 79.0 & 1.5 & 0.4 & 91.0 & 1.5 & 1.0 & 85.0 & 1.5 & 0.7 & 7190 & 7490 & 7340 \\
\hline C.D. at $5 \%$ & 6.8 & 0.6 & NS & 7.0 & 0.5 & NS & 6.9 & 0.5 & NS & 1170 & 1000 & 1260 \\
\hline C.V. & 4.1 & 26.6 & 7.7 & 4.8 & 11.2 & 5.9 & 4.4 & 8.1 & 7.3 & 9.2 & 7.5 & 8.4 \\
\hline
\end{tabular}

L: length $(\mathrm{cm})$, B: width $(\mathrm{cm})$, and W: weight $(\mathrm{kg})$.

TABle 5: Growing degree days (GDDs) and photo thermal units (PTUs) accumulation of Acorus calamus (sweet flag) as influenced by staggered harvesting over two seasons and years.

\begin{tabular}{|c|c|c|c|c|c|c|c|c|c|c|c|c|}
\hline \multirow{3}{*}{ Harvest time } & \multicolumn{6}{|c|}{ GDD from planting to harvesting } & \multicolumn{6}{|c|}{ PTU from planting to harvesting } \\
\hline & \multicolumn{3}{|c|}{ Rainy } & \multicolumn{3}{|c|}{ Autumn } & \multicolumn{3}{|c|}{ Rainy } & \multicolumn{3}{|c|}{ Autumn } \\
\hline & 2006-2007 & $2007-2008$ & Mean & 2006-2007 & 2007-2008 & Mean & 2006-2007 & $2007-2008$ & Mean & 2006-2007 & 2007-2008 & Mean \\
\hline At 7 th month & 3911 & 3670 & 3791 & 4008 & 3939 & 3974 & 46831 & 44003 & 45417 & 49612 & 48793 & 49202 \\
\hline At 8th month & 4365 & 4122 & 4244 & 4705 & 4672 & 4688 & 51750 & 48896 & 50323 & 58809 & 58455 & 58632 \\
\hline At 9th month & 4846 & 4548 & 4697 & 5411 & 5399 & 5405 & 57180 & 53709 & 55444 & 67787 & 67692 & 67740 \\
\hline At 10 th month & 5476 & 5221 & 5349 & 6096 & 6093 & 6095 & 64698 & 61744 & 63221 & 76077 & 76074 & 76075 \\
\hline At 11 th month & 6244 & 5980 & 6112 & 6714 & 6734 & 6724 & 74352 & 71294 & 72823 & 83149 & 83406 & 83277 \\
\hline At 12 th month & 7106 & 6865 & 6985 & 7208 & 7263 & 7235 & 85639 & 82891 & 84265 & 88538 & 89173 & 88855 \\
\hline Mean & 5325 & 5068 & 5196 & 5690 & 5683 & 5687 & 63409 & 60423 & 61916 & 70662 & 70599 & 70630 \\
\hline
\end{tabular}

by $20 \times 20 \mathrm{~cm}$ spacing $\left(8660 \mathrm{~kg} \mathrm{ha}^{-1}\right)$ in the previous year 2006-07 (Table 4). The least yield was recorded in $40 \times$ $30 \mathrm{~cm}$ spacing $\left(6060 \mathrm{~kg} \mathrm{ha}^{-1}\right)$ during 2007-08 followed by $40 \times 40 \mathrm{~cm}$ spacing $\left(6390 \mathrm{~kg} \mathrm{ha}^{-1}\right)$ during 2006-07. It was found that planting of $A$. calamus in close spacings $(20 \times$ $20 \mathrm{~cm}$ and $30 \times 20 \mathrm{~cm}$ ) brought significantly greater yield than wider spacings $(40 \times 40 \mathrm{~cm}$ and $40 \times 30 \mathrm{~cm})$ over two years. However, the mean rhizome yield was higher in 2007-08 than the preceding year, which may be due to better weather conditions for crop production (Tables 1 and 4). Yield increase was earlier reported in narrow spacings for soybeans [27-29]. Similarly, Ahmed and Rahman [30] reported that plant spacing significantly affects the yield of turmeric rhizome. One of the benefits of higher plant density associated with the use of narrow spacing is its contribution to earlier canopy closure, which makes weed control easier by increasing competition between the crop and weeds. The significant increase in yield of $A$. calamus rhizomes under closer spacing may solely be ascribed on the function of higher plant density per unit area of land and as the spacing increased, yield reduction of rhizome was experienced by the crop leading to slight yield increase in the widest spacing. Similar findings were observed by Sashidhar et al. [31]. Yield-dependant components were significantly $(P \leq 0.05)$ higher in closer spacing $(20 \times 20 \mathrm{~cm})$, giving good growth of
A. calamus over two years. This was evident by the pooled maximum rhizome length plant ${ }^{-1}(89.5 \mathrm{~cm})$, width plant ${ }^{-1}$ $(1.6 \mathrm{~cm})$, and weight plant ${ }^{-1}(0.7 \mathrm{~kg})$ which were recorded in $20 \times 20 \mathrm{~cm}$ versus other spacings. Least pooled values of yield components were recorded in wider spacing $(40 \times 40 \mathrm{~cm})$, that is, length plant ${ }^{-1}(80.8 \mathrm{~cm})$, width plant ${ }^{-1}(1.4 \mathrm{~cm})$, and weight plant ${ }^{-1}(0.7 \mathrm{~kg})$. Trial means of two years showed that rhizome length plant ${ }^{-1}$, width plant ${ }^{-1}$, and weight plant ${ }^{-1}$ were higher in 2006-07 than in 2007-08 (Table 4). In 200607 , rhizome length plant $^{-1}$ recorded from spacing $30 \times$ $20 \mathrm{~cm}$ and $40 \times 40 \mathrm{~cm}$ was almost equal and statistically nonsignificant, whereas in 2007-08, the same was observed between spacing $30 \times 40 \mathrm{~cm}$ and $40 \times 40 \mathrm{~cm}$. Rhizome width plant $^{-1}$ and weight plant ${ }^{-1}$ were not significant $(P \leq 0.05)$ among the treatments. Bahadur et al. [32] reported that close spacing caused taller plant height and brought significantly higher yield of rhizome of Curcuma longa var. Sinduri.

The present investigation illustrated substantial yield increase of Acorus calamus rhizome by planting the crop in closer spacing and by harvesting the plants after one year. The study also suggested the planting of Acorus calamus in autumn season to obtain greater yield. Moreover, the yieldcontributing characteristics of the rhizomes also showed a similar trend. These findings are of prime importance for increasing rhizome yield of Acorus calamus in favorable soil 
conditions, particularly in India. The study also laid a strong foundation for the conservation of this important ethnomedicinal plant species, which is used worldwide.

\section{Acknowledgments}

The research work was conducted under Adhoc project funded by Chhattisgarh Council of Science and Technology (CGCOST) Raipur, Chhattisgarh, India. The authors are also thankful to Agro-Meteorology Observatory of T.C.B. College of Agriculture and Research Station (IGKV) Bilaspur, Chhattisgarh, India.

\section{References}

[1] FAO, AGROSTATE "Information System on Food and Agriculture", FAO, Rome, Itlay, 1999.

[2] D. J. Andrews and A. H. Kassam, "The importance of multiple cropping in increasing world food supplies," in Multiple Cropping, R. I. Papendick, A. Sanchez, and G. B. Triplett, Eds., pp. 1-10, American Society of Agronomy, Madison, Wis, USA, 1976, ASA Special Publication 27.

[3] V. P. Singh and R. N. Yadav, Water and Enviornment-Waste Water Treatment and Waste Management, Allied Publisher Pvt. Ltd, New Delhi, India, 2003, A 104-Mayapuri II.

[4] K. L. Nandeha, T. D. Pandet, D. S. Thakur et al., "Evaluation of rice-sweet flag (Acorus calamus) intercropping system," in Proceedings of the International Symposium on Rainfed Rice Ecosystems: Perspective and Potential, p. 95, IGAU, Raipur CG, India, 2004.

[5] W. C. Beets, Raising and Sustaining Productivity of Smallholder Farming Systems Tropics, AgBé Publishing, Alkmaar, The Netherlands, 1990.

[6] R. K. S. Tiwari, V. B. Shambharkar, N. K. Chaure, and B. S. Thakur, "Prospect of cultivation of Acorus calamus (Bach) under rainfed rice ecosystem," in Proceedings of the Abstracts of International Symposium on Rainfed Rice Ecosystems: Perspective and Potential, pp. 161-162, IGAU, Raipur CG, India, 2004.

[7] R. K. S. Tiwari, V. B. Shambharkar, and B. M. Ojha, "Prospect and potential of medicinal herbs. I. E. Acorus calmus (Bach) and Bacopa monieri (Brahmi) under rice based ecosystem," in Proceedings of the Abstract of National Seminar on Medicinal Aromatic Plants-Biodiversity, Conservation, Cultivation and Processing, pp. 106-107, IGAU, Raipur CG, India, 2005.

[8] R. Balakumbahan, K. Rajamani, and K. Kumanan, "Acorus calamus: an overview," Journal of Medicinal Plant Research, vol. 4, no. 25, pp. 2740-2745, 2010.

[9] R. Bentley and H. Trimen, Medicinal Plants, vol. 4, 1st edition, 1983.

[10] I. G. Vassi and H. C. Patel, Comparative Physiology andEcology, vol. 12, no. 1, pp. 49-51, 1987.

[11] T. J. Motley, "The ethnobotany of sweet flag, Acorus calamus (Araceae)," Economic Botany, vol. 48, no. 4, pp. 397-412, 1994.

[12] P. Mamgain and R. H. Signh, "Controlled clinical trial of the lekhaniya drug vaca (Acorus calamus Linn.) in cases of ischaemic heart diseases," Journal of Research in Ayurveda and Siddha, vol. 15, no. 1-2, pp. 35-51, 1994.

[13] K. Keller, K. P. Odenthal, and E. Leng-Peschlow, "Spasmolytic action of Acarus calmus oil free from $\beta$-asarone," Planta Medica, vol. 1, pp. 6-9, 1985.
[14] M. D. Parikh, P. V. Prada, L. P. Shah, and V. N. J. Bagadia, "Evaluation of Indigenous Psychotoropic Drugs-A Preliminary Study," Research Ayurvedic Sidha, vol. 5, no. 1-9, pp. 1217, 1984.

[15] A. E. Raja, M. Vijayalakshmi, and G. Devala Rao, "Acorus calamus Linn: chemistry and biology," Research Journal of Pharmacy and Technology, vol. 2, no. 2, pp. 256-261, 2009.

[16] J. F. Caius, The Medicinal and Poisonous Plants of India, Scientific Publishers, Jodhpur, India, 1986.

[17] McAlpine Thorpe \& Warrier Limited, Future World Trends in the Supply, Utilisation, and Marketing of Endangered Plant Species, McAlpine Thorpe \& Warrier Limited, London, UK, 1996.

[18] L. V. Asolkar, K. K. Kakkar, and O. J. Chakre, 2nd Supplement to glossary of Indian Medicinal plants with active principles. CSIR, pp. 18, 1992.

[19] P. Oudhia, "Improved cultivation practices for medicinal crops: glimpses of research of farmers' fields in Chhattisgarh (India)," in Proceedings of the National Research Seminar on Herbal Conservation, Cultivation, Marketing and Utilization with Special Emphasis on Chhattisgarh, P. Oudhia, Ed., pp. 1314, The Herbal State, Srishti Herbal Academy and Research Institute (SHARI), 2001, Souvenir-cumabstracts.

[20] D. D. Verma, "Cultivation of rice with buch: a study," in Proceedings of the National Research Seminar on Herbal Conservation, Cultivation, Marketing and Utilization with Special Emphasis on Chhattisgarh, P. Oudhia, Ed., p. 54, The Herbal State, Srishti Herbal Academy and Research Institute (SHARI), 2001, Souvenir-cum-abstracts.

[21] S. K. Pal, U. N. Verma, M. K. Singh, and R. Thakur, "Heat-unit requirement for phenological development of wheat (Triticum aestivum) under different levels of irrigation, seeding date and fertilizer," Indian Journal of Agricultural Sciences, vol. 66, no. 7, pp. 397-400, 1996.

[22] N. K. Chaure, D. Pandey, and B. S. Thakur, "Effect of climatic parameters on evapotranspiration during rainfed rice ecosystem," Environment and Ecology, vol. 25, no. 3, pp. 670-672, 2007.

[23] K. A. Gomez and A. A. Gomez, Statistical Procedures for Agricultural Workers, International Rice Research Institute Book, John Wiley \& Sons, New York, NY, USA, 2nd edition, 1983.

[24] G. S. McMaster and W. W. Wilhelm, "Growing degree-days: one equation, two interpretations," Agricultural and Forest Meteorology, vol. 87, no. 4, pp. 291-300, 1997.

[25] C. P. Wilsie, Crop Adoptation and Distribution, W. H. Freeman, London, UK, 1962.

[26] Y. Ramakrishna, S. Singh, and S. S. Parihar, "Influence of irrigation regime and nitrogen management on productivity, nitrogen uptake and water use by rice (Oryza sativa)," Indian Journal of Agronomy, vol. 52, no. 2, pp. 102-106, 2007.

[27] H. R. Boerma and D. A. Ashley, "Irrigation, row spacing, and genotype effects on late and ultra-late planted soybeans," Agronomy Journal, vol. 78, pp. 995-1002, 1982.

[28] R. R. Johnson, "Crop management," in Soybeans: Improvement, Production, and Uses, J. R. Wilcox, Ed., pp. 355-390, American Society of Agronomy, Madison, Wis, USA, 2nd edition, 1987.

[29] L. G. Heatherly, "Planting date, row spacing, and irrigation effects on soybean grown on clay soil," Agronomy Journal, vol. 8, pp. 227-231, 1988.

[30] N. U. Ahmed and M. M. Rahman, "Effect of seed size and spacing on the yield to turmeric," Bangladesh Journal of Agricultural Research, vol. 12, pp. 50-54, 1987. 
[31] T. R. Sashidhar, G. S. Sulikeri, and V. D. Gasti, "Effect of different spacing and nitrogen levels on the growth attributes and the dry matter production of turmeric (Curcuma longa L.) cv. amalapuram," Mysore Journal of Agricultural Sciences, vol. 31, pp. 225-229, 1997.

[32] M. M. Bahadur, A. K. M. Azad, M. A. Hakim, S. M. M. Hossain, and S. P. Sikder, "Effect of different spacing and potassium level on the growth and yield of turmeric var. sinduri," Pakistan Journal of Biological Sciences, vol. 3, no. 4, pp. 593595, 2000. 


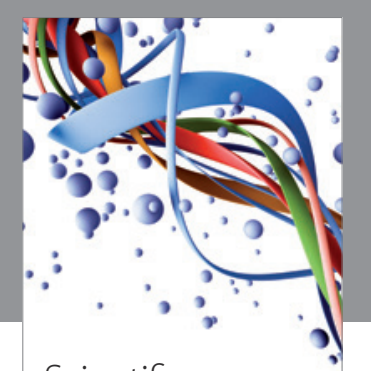

Scientifica
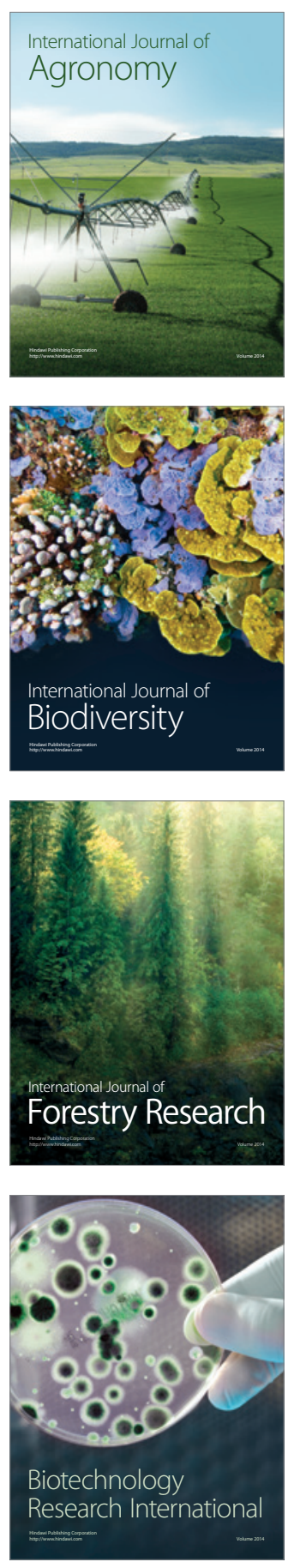
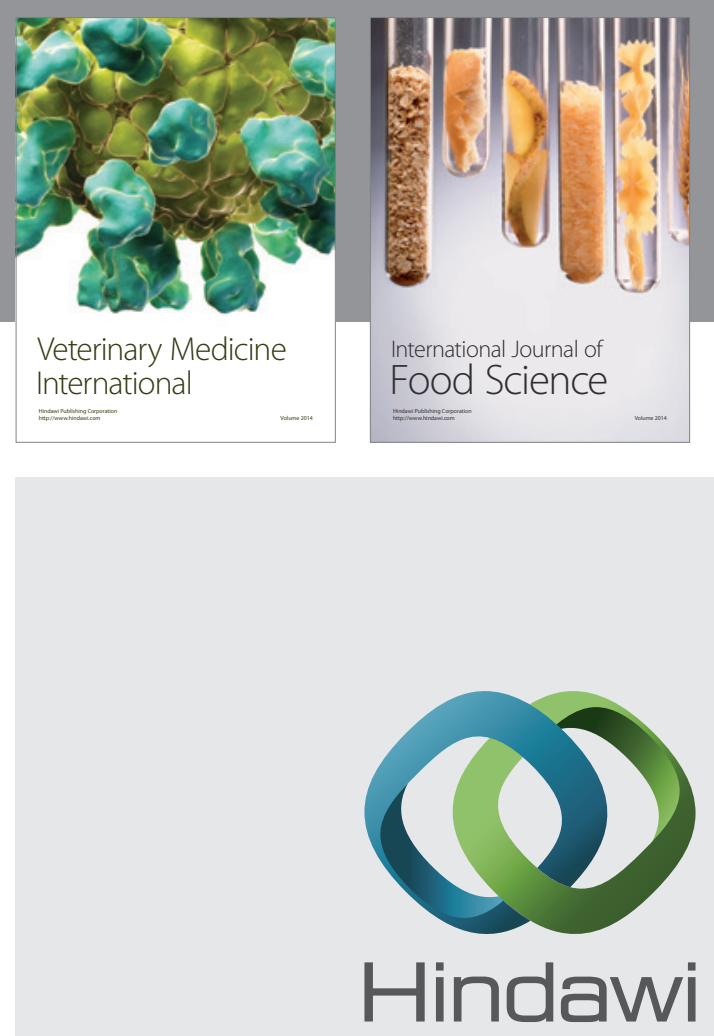

Submit your manuscripts at

http://www.hindawi.com
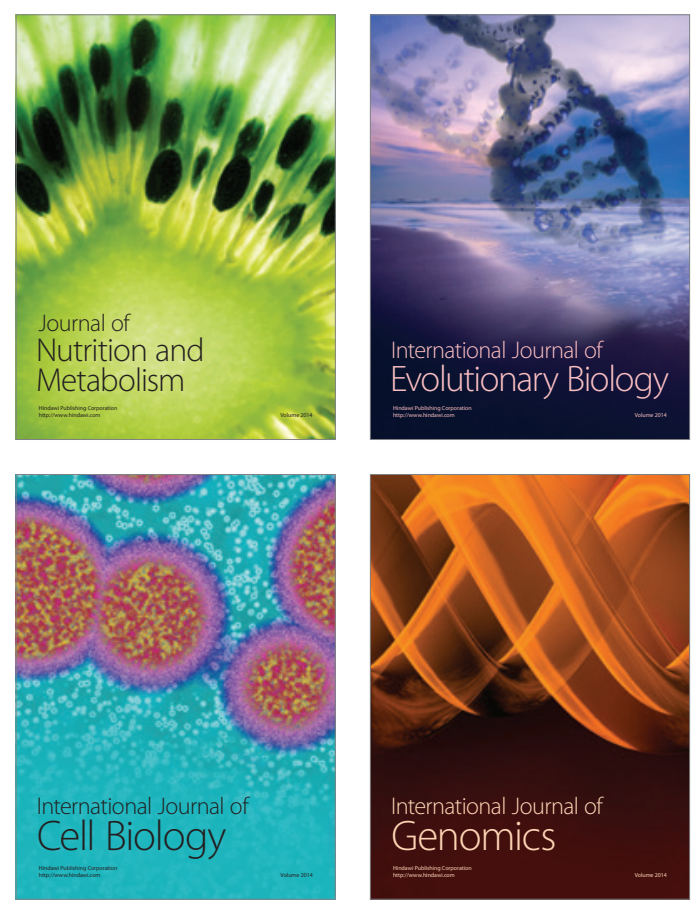
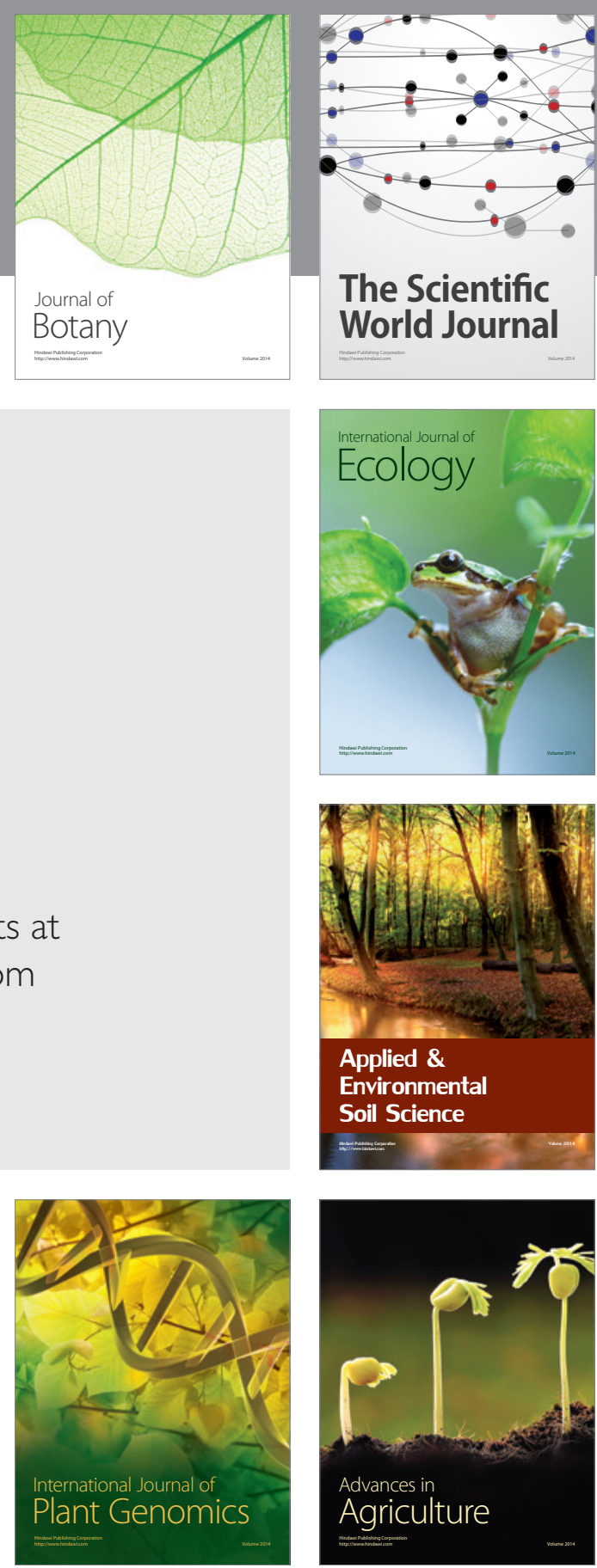

The Scientific World Journal
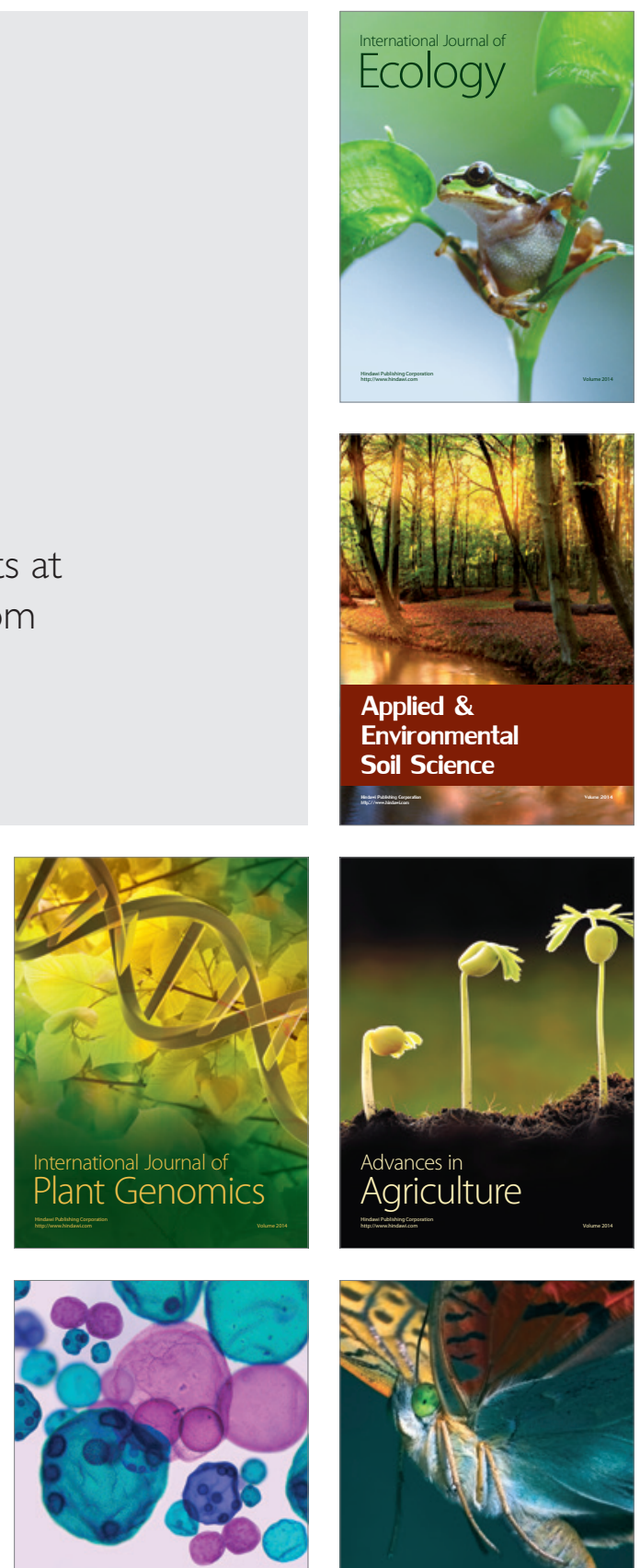

International Journal of Microbiology

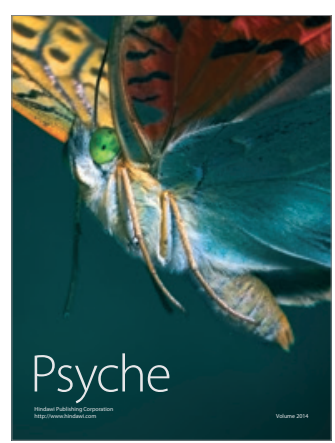

